\title{
Pengaruh Pembinaan Warga Jemaat Terhadap Pertumbuhan Kerohanian Jemaat GKII Long Pua
}

\author{
Julianti Kayang
}

\begin{abstract}
Abstrak
Adapun tujuan penulisan skripsi ini, adalah: Untuk mengetahui sejauh mana pengaruh pembinaan warga jemaat terhadap pertumbuhan kerohanian jemaat GKII Long Pua. Berdasarkan hasil penelitian maka penulis menyimpukan bahwa: Pertama, Bentuk- bentuk pelayanan yang dilakukan dalam membina pertumbuhan kerohanian jemaat Gereja Kemah Injil Indonesia Long Pua adalah melalui pelayanan: (1) Konseling, (2) Bimbingan (3) PengajaranAlkitab, (4) Perkunjungan. Kedua, faktor yang mempengaruhi pertumbuhan kerohanian jemaat tersebut adalah perkataan tidak memberkati, iri hati dan mementingkan diri sendiri, hal ini terjadi atas kurangnya pelayanan konseling, bimbingan, perkunjungan dan pengajaran Alkitab yang dilakukan kepada anggota jemaat. Ketiga, unsur-unsur dalam meningkatkan pertumbuhan kerohanian jemaat Gereja Kemah Injil Indonesia Long Pua ialah melalui: (1) Penyembahan, (2) Pengajaran firman Tuhan, yaitu melalui pelayanan kotbah (3) Persekutuan, (4) Keterlibatan anggota jemaat dalam pelayanan.
\end{abstract}

Kata-kata Kunci: Pengaruh, Pembinaan, Jemaat, Pertumbuhan, Kerohanian, Long Pua

\section{Pendahuluan}

\section{Latar Belakang Masalah}

Tulisan ini dilatar belakangi oleh apa yang telah diamati peneliti pada waktu melaksanakan praktek kuliah lapangan di jemaat GKII long pua. Menurut peneliti bahwa pembinaan terhadap warga jemaat sering kali terabaikan kerena gembala tidak aktif dalam jemaat demikian juga dengan anggota jemaat selalu sibuk dengan aktifitas sehari-hari. Karena ketidak aktif seorang gembala di tempat pelayanan maka pembinaan terhadap pertumbuhan rohani warga jemaat tidak terlaksana dengan baik sehingga banyak anggota jemaat yang belum bertumbuh secara dewasa di dalam Tuhan. Berkhotbah dan doa syafaat seorang gembala tidaklah cukup untuk membawa anggota jemaat kepada pertumbuhan rohani.J. Oswald Sanders mengatakan bahwa:"Masalahnya bukanlah kita memerlukan lebih banyak waktu lagi, melainkan 
bagaimana memanfaatkan waktu kita secara lebih baik."1 Oleh sebab itu seorang pembina warga jemaat atau gembala yang baik harus lebih peka terhadap kebutuhan rohani anggota jemaatnya, karena dengan demikian ia dapat memenuhi kebutuhan rohani setiap pribadi anggota jemaatnya dan bisa memanfaatkan waktu pelayanannya dengan penuh tanggung jawab kepada Allah.

Tujuan dari pembinaan yang dilakukan oleh seorang pembina warga jemaat ialah memimpin tiap-tiap orang kepada kesempurnaan dalam Yesus Kristus (Kolose 1:28) mengatakan bahwa "Dialah yang kami beritakan, apabila tiap-tiap orang kami nasihati dan tiap-tiap orang kami ajari dalam segala hikmat, untuk memimpin tiaptiap orang kepada kesempurnaan dalam Kristus."2 Oleh sebab itu sebagai seorang pembina atau gembala dalam suatu jemaat haruslah memperhatikan kebutuhan rohani dari setiap anggota jemaatnya supaya anggota jemaat merasa dirinya diperhatikan dan dapat bertumbuh secara dewasa di dalam Kristus karena dasar pembinaan yang dilakukan adalah pola ajaran Alkitab. Untuk itu dalam membina anggota jemaat kepada pengenalan akan Kristus seorang pembina haruslah menjadi teladan dalam perkataan dan tingkah laku, rendah hati, murah hati, tidak sombong kepada setiap anggota jemaat yang dilayani. Perlu diingat bahwa dalam membina suatu jemaat terdapat beberapa prinsip utama yang menjadi tugas seorang pembina warga jemaat yaitu: memberitakan firman Tuhan kepada setiap anggota jemaat yang membutuhkan, mendoakan serta menguatkan dan mengajarkan anggota jemaat menjadi orang Kristen yang setia kepada Allah dan memprioritaskan Allah dalam kehidupan sehari-hari.

Zaman sekarang ini ada banyak orang-orang Kristen yang merosot di dalam kerohanian, sehingga tidak mejadi teladan yang baik ditengah dunia, oleh sebab itu peran seorang pembina atau gembala sangat dibutuhkan oleh setiap pribadi anggota jemaat yang dilayaninya. Meningkatnya keinginan anggota jemaat untuk selalu mengikuti persekutuan, baca firman Tuhan, berdoa serta terlibat dalam pelayanan, tergantung pembawaan pembina warga jemaat yang melayani bagaimana caranya pembina warga jemaat tersebut membangun rohani jemaatnya dengan pelayanan yang dilakukan kepada setiap pribadi anggota jemaatnya. Memperhatikan kebutuhan rohani setiap pribadi anggota jemaat merupakan tanggung jawab seorang pembina atau seorang gembala yang melayani anggota jemaat tersebut. Jika seorang pembina memperhatikan kebutuhan rohani anggota jemaatnya kemungkinan besar anggota jemaat akan mengalami perubahan yang tentunya menuju kepada pertumbuhan rohani yang baik.

\footnotetext{
${ }^{1}$ J. Oswald Sanders, Kepemimpinan Rohani(Bandung: Yayasan Kalam Hidup, 1974), 95.

${ }^{2}$ Kolose 1:28 (TB).
} 


\section{Pokok Masalah}

Berdasarkan latar belakang penelitian diatas maka masalah pokok dalam penelitian ini adalah sejauh mana pengaruh pembinaan warga jemaat terhadap pertumbuhna kerohanian jemaat GKII Long Pua?

\section{Tujuan Penelitian}

Tujuan penelitian adalah untuk mengetahui sejauh mana pengaruh pembinaan warga jemaat terhadap pertumbuhan kerohanian jemaat GKII Long Pua.

\section{Manfaat Penelitian} berikut:

Dari hasil penelitian tersebut diharapkan dapat memberi manfaat sebagai

Pertama, untuk menambah wawasan dan pengetahuan bagi peneliti dalam penyusunan skripsi ini.

Kedua, untuk menambah pengetahuan bagi para pembaca skripsi ini.

Ketiga, sebagai bahan teori dan praktek bagi para pelayan Tuhan yang melayani khususnya dalam membina pertumbuhan kerohanian jemaat yang ada dijemaat GKII Long Pua.

Keempat, sebagai bahan teori bagi para hamba Tuhan yang melayani sedaerah pujungan tentang pentingnya pembinaan warga jemaat itu dilakukan pada setiap jemaat agar anggota jemaatnya dapat bertumbuh secara dewasa di dalam Tuhan.

Kelima, sebagai salah satu persyaratan untuk menyelesaikan Studi Serjana Pendidikan Agama Kristen di STT Jaffray Makassar.

\section{Metode Penelitian}

Metode penelitian yang digunakan oleh peneliti dalam penyusunan skripsi ini adalah metode kuantitatif dengan teknik pengumpulan data sebagai berikut:

Pertama, kepustakaan guna untuk mengumpul data dan informasi dari bukubuku yang erat hubungannya dengan judul penelitian.

Kedua, menggunakan angket (kuesioner) ${ }^{3}$ guna untuk mengetahui sejauh mana pengaruh pembinaan warga jemaat terhadap pertumbuhan kerohanian jemaat setempat.

\section{Batasan Penelitian}

Di dalam penelitian ini peneliti membatasinya pada pengaruh pembinaan warga jemaat terhadap pertumbuhan kerohanian jemaat GKII Long Pua yang mencakup upaya yang dilakukan untuk membina warga jemaat agar dapat bertumbuh secara dewasa di dalam Tuhan.

\footnotetext{
${ }^{3}$ Hengki Wijaya (ed.), Metodologi Penelitian Pendidikan Teologi (Makassar: Sekolah Tinggi
} Theologia Jaffray, 2016), 26. 


\section{Kepustakaan}

Alkitab. Jakarta: Lembaga Alkitab Indonesia, 2009.

Sanders, J. Oslwald. Kepemimpinan Rohani. Bandung: Kalam Hidup, 2000.

Simanjuntak, Junihot M. "Implikasi Konsep Dan Desain Kurikulum Dalam Tugas

Pembinaan Warga Jemaat.” Jurnal Jaffray 12, no. 2 (2014).

http://dx.doi.org/10.25278/ji71.v12i2.18

Wijaya, Hengki (ed.). Metodologi Penelitian Pendidikan Teologi. Makassar: Sekolah Tinggi Theologia Jaffray, 2016. 